\title{
APPRAISING OBSTACLES TO FEMALE CAREER DEVELOPMENT IN BANKS: A STUDY OF SITUATION IN NIGERIAN MONEY DEPOSIT BANKS
}

\author{
OBI-ANIKE, HAPPINESS OZIOMA ${ }^{1}$ \\ email: ozioma.obi-anike@unn.edu.ng \\ University of Nigeria Enugu Campus \\ AGU OKORO AGU ${ }^{2}$ \\ Don_okojomboagu@yahoo.com
}

Evangel University Okpoto, Abakaliki- Ebonyi State

EZIEFULE, CHINYERE ADAMMA ${ }^{3}$

University of Nigeria Enugu Campus

\begin{abstract}
The study sought to determine effect of female career development on performance Money Deposit Banks, identify the obstacles of female career development in money deposit banks. The study had a population size of 3152, out of which a sample size of 354 was realised using taro Yamane's formula at 5\% error tolerance and 95\% level of confidence. Instrument used for data collection was primarily questionnaire and interview. Out of 354 copies of the questionnaire that were distributed, 334 copies were returned while 47 were not returned. The survey research design was adopted for the study. The hypotheses were tested using Pearson chi-square and simple linear regression statistical tools. The findings indicated that Female career development significantly affects performance of money deposit banks $(r=0.766 ; t=$ 13.191; $F=52.361 ; p<0.05)$. Glass ceiling, Gender inequality and cultural factor are the obstacles of female career development in money deposit banks $\left(X_{c}^{2}=136.379,>X^{2}{ }_{t}=31.419 ; p,<.05\right)$. The study concluded that women world-wide can be seen joining the workforce in large numbers. Women managers globally are described as having to deal with blocked mobility, discrimination and stereotypes..The study recommended that The equality theory should be adopted in any money deposit banks, and gender issues should be a thing of the past, but employee input should determine their reward system and promotion. In order increase productivity government should empower women and protect their labour rights and the environment through the policies put in place
\end{abstract}

Keywords: Female Career Development, Money Deposit Bank and Nigeria

\section{Academic Discipline And Sub-Disciplines}

Human Resource Management;

\section{TYPE (METHOD/APPROACH)}

Survey/Interview

\section{INTRODUCTION}

In this $21^{\text {st }}$ century women as well as gender issues have turn into a major area of concern. Seminars, workshops are being held over the world to discuss women issues and women progression in all area of life. That is because of the most significant features of the global labor market in the last half of the twentieth century, which is increasing the participation of women. (Black, Gregerson, Mendenhall and Stroh, 1999; Caligiuri and Tung, 1999). Changing economic circumstances and new technology are changing the ways people look for work, both inside and outside organizations. This has given rise to an increasing range of intermediary organizations offering some forms of career guidance alongside their other activities. Career development is a critical issue that had called attentions of scholars, researchers, decision makers and human resources experts. In human capital development these stakeholders have striven to manage issues such as recruitment, selection, training and development, promotion, and so on emanating from career development.

Organizations need to realize that positive career development for their workforce is a way of helping to attract and retain the best people: by recognizing and responding to the needs of individual employees they will get the best out of them. More effective guidance will assist the development of a knowledge economy and benefit individuals, employers and society at large. It will, however, require a cultural shift in management behaviour in organizations towards selfmanagement (Hackman, 1986).

Female workers who identified having difficulties balancing work and family indicated that they had too many work and family responsibilities and sometimes they did not have time to accomplish everything effectively. To them, time management was the biggest challenge. To avoid the Family Barriers organization can help with the female workers by offering day care centers, leave them in the weekends, giving same flexible office hours and home office. Some can argue that leaving the females in weekends will affect the organization performance but to get the fullest contribution of the 
creative's, talented organization must give something and expect something from them. Other factor is that our society has been built to bear the family responsibilities to women hence that must be a fair reason to give little bit freedom to them. Women are affectionately referred to as the life-blood of any organization and, at the same time, are also known as the 'Subordinate Sector' (Maxwell and Florence, 2010). It is difficult to envisage a society or organization without them. "Some women feel exhausted by the battles they face in the workplace - especially when they chose to work flexibly to manage work/life balance. For those trying to progress there is often a lack of senior management support for promotion or development. There is also the problem of 'long hours culture'.

The glass ceiling syndrome was coined by Wall Street Journal some years ago to mean an organizational invisible, implicit but impenetrable barriers that prevent women from achieving parity with their male counterparts at the highest levels of the corporate ladder (Maxwell, 2007). Catalyst (2004) found that companies with a higher representation of women in top management jobs financially outperform companies with fewer women at the top. Despite these achievements, women still strive to emerge and grow out of male oppression and move to higher levels. A woman's primary role in the family is as a wife and mother. Many employers feel that these roles will interfere with women's work productivity. Hence, there is a tendency for them to give priority to men in terms of employment and promotion, even where women have the same qualifications (Omair, 2008). Also they found out that majority of women feel there is a lack of networking among businesswomen for exchanging information, discussing issues and seeking advice on common topics. Some of these women have started to form such networks.

According to Ilagan-Bian (2004), women faced many challenges in moving up such as non-supportive bosses or colleagues, sexual discrimination and male chauvinism. Women still list male prejudice and the "old boy network" as the main obstacles to their progress (Clutterbuck \& Devine, 1987; Ilagan- Bian, 2004). To achieve equal status, the requirement level for women to achieve in the workplace, is set at a much higher standard, they are required to work harder, be more qualified, more ambitious and competent than their male counterparts (Bryce, 1989) A lack of women in senior positions who mentor and encourage other women is the single most important issue facing women in business (Baker \& Mckenzie, 2001). Wage discrimination is another barrier which women face because they do not receive equal pay for equal work. "Women still earn substantially less than men (Bryce, 1989).

\section{Statement of Problem}

Socially and culturally, women and men have tended to assume different roles, duties, and identities in their respective organizations and they often encounter different challenges. Despite having entered the workforce with credentials and expectations similar to those of men, women encounter many obstacles as organizations reflect diverse and gendered realities of life. Their marginal status has led to the endemic problems of their roles in organizations being constrained and strangled by gender role stereotyping. The persistent stereotyping that associates management with maleness contributes to the resistance of female leadership, discrimination, and a host of other challenges. Women in management positions are therefore held back in terms of exercise of duty and performance. Catalyst, a women's advocacy group, reported that the most common barriers for women include concerns about their suitability for leadership positions because of stereotyping, exclusion from informal networks of communication, and an absence of effective management training. Other common obstacles include the failure of upper level managers to be accountable for the development and advancement of women, inadequate appraisal and compensation systems, inflexibility in defining work schedules, and the absence of programs that help employees balance work and non-work responsibilities

\section{Objectives of the study}

The specific objectives were to

1 To determine effect of female career development on performance Money Deposit Banks

2 To identify the obstacles of female career development in money deposit banks

\section{Research Questions}

With the above objectives in focus, the study seeks to find answers to the following questions

1 What are the effect of female career development on performance Money Deposit Banks?

2 What are the obstacles of female career development in money deposit banks?

\section{Research Hypotheses}

These hypotheses were proposed for the study

1 Female career development significantly affect performance of money deposit banks

2 Glass ceiling, Gender inequality and cultural factor are the obstacles of female career development in money deposit banks

\section{Review of Related Literature}

\section{Conceptual framework}

London and Stumpf (1982) define career development as "the activities individuals participate in to improve themselves relative to their current or planned work roles. Similarly, Sears (1982) refers to career development as "the total 
constellation of psychological, sociological, educational, physical, economic, and chance factors that combine to influence the career of any given individual over the life span".

\section{Factors Affecting career development of women}

It first looks at gender inequality, chauvinism and sexual harassment, organizational structure, the glass ceiling effect and discrimination at the workplace.

\section{Gender Inequality}

Gender inequality is particularly prominent in the professions today, where women are concentrated in those occupations which are relatively low in the professional hierarchy (Turner 1986). Gender issues in today's workplace can be traced to the different ways that women and men perceive the world (Banducci, 2002). Banducci adds that people are different and we need to understand those differences and act in a way to maximize the value of these differences. These gender inequalities are costly to any country's economic development as well as the well being of its people (World Bank, 1995).

\section{Chauvinism and Sexual Harassment}

Male chauvinism in our country is deeply ingrained than many people realize. Gender sensitivity and sexual harassment concerns both men and women. Women generally bear the brunt of male chauvinism as well as sexual harassment Issues such as gender bias, gender sensitivity and sexual harassment concern both men and women in working towards a nation that is committed to rights. Sexual harassment stands out as the key contemporary site of gender struggles over gender norms, sexuality, power and gender equality, as well as legal and organizational norms (Zippel, 2002).

\section{Organizational Structure}

Organizations structures often mirror the society's ideas on what groups of workers are appropriate for certain jobs Occupations that are usually labeled as "men's" jobs are not equally distributed across different racial groups (Xu \& Leflar, 1992).Those who advocates a "color blind" or "sex blind" approach to hiring and promotions ignore the fact that the usual racial and sexual biases will persist without intervention. (Blumberg, 1987).

\section{The Glass Ceiling Effect}

The Glass Ceiling effect is defined by the Labor Department in New York as artificial barriers based on bias that prevents qualified individuals progressing in upper management levels in an organization. Where the glass ceiling is present, women receive lower paying positions. This has a detrimental effect on the morale and economy of any corporation. Women are the most visible victims of the real glass ceiling due to the deeply ingrained attitudes at the lower levels (Savage, 2002).

\section{Cultural Factors}

Culturally, society believed a woman's place was in her home, caring for her husband and children, as opposed to the workplace. Valued feminine traits such as meek nature and submissiveness were feared to be lost if women entered the workforce (Astin, 1984; Nieva and Gutek, 1981). Women commonly assisted their husbands with maintaining the family or acted as a business partner, although they often received no pay. If they were paid for their work, women earned less than their male counterparts (Nieva and Gutek, 1981).

\section{Structural Factors}

It has been found that many women academics feel that there is lack of career guidance and collaborative goal setting Human resource departments (Bain and Cummings, 2000). This can lead to disadvantages for women a in their career planning. Different degrees of formality may be used to identify potential for promotion in the firm. These may ultimately limit the possibility of progression for women in career progression.

\section{Theory Framework}

\section{Rawls' theory of justice}

Rawls' theory of justice revolves around the adaptation of two fundamental principles of justice, which would, in turn, guarantee a just and morally acceptable society. The first principle guarantees the right of each person to have the most extensive basic liberty compatible with the liberties of others. The second principle states that social and economic positions are to be to everyone's advantage and open to all (Nussbaum, 2000).

\section{Empirical framework}

Sen, Kandpal and Tinani (2013) conducted a study on the road to the top- barriers faced by women in the financial sector in Oman. According to statistics available, women world-wide can be seen joining the workforce in large numbers. The same trend is observed in Oman, where women can be seen working in large numbers in the services sector, especially in the Financial sector. Although they form such a large proportion, almost $50 \%$, of the working population, they still lag behind when it comes to career advancement. This study tries to identify the barriers to career advancement of women in the financial sector in Oman. Some of the statistical tests used are Chi-square and descriptive statistics like Mean and Principal Component Analysis. A definite association was found between the barriers identified and career advancement of women in the financial sector in Oman 
Osibanjo, Oyewunmi, and Ojo, (2014) carried out a study on Career Development as a Determinant of Organizational Growth: Modelling the Relationship between these Constructs in the Nigerian Banking Industry .A sample was drawn from First City Monument Bank (FCMB) with two hundred and sixty five respondents. SPSS was used to analyze demographic characteristics of the respondents, while AMOS 21 was adopted for the Structural Equation modeling of the survey model. Results: Many of the associations between the tested variables were strong and positive. However, all the tested independent variables such as reward, recognition, skills, promotion had positive impact on organizational growth, while experience had negative impact. Conclusion: Results support the literature, in terms of the relationships between independent and dependent variables with the exception of experience, which had negative impact on organizational growth. Therefore, management should employ better strategies in retaining their experienced employees, which tends to effect on the organizational growth

David (2014) explores the moderating effects of gender on the job insecurity - career engagement relationship. The survey involved 223 Nigerian bank employees who gave their personal consent to take part in the research. Results of the hierarchical regression analysis revealed that a significant negative relationship exists between perceived job insecurity and career engagement $(b=-.67, p<.001)$. The moderator effects of gender on the negative relationship between perceived job insecurity and career engagement was significant $(b=.20, p<.001)$. The negative relationship was found to be stronger for men than for women at any particular level of job insecurity. In contrast to expectation, women reported significantly higher levels of career engagement than their male colleagues

Satope (2014) examined a study on Finance, development and growth in Nigeria: Obstacles, steps adopted and DOHA recommendation. A close relationship is said to exist between the three variables: economic growth, economic development and financial development (Kehinde and Adejuwon, 2011). There are many factors determining growth which were divided into demand and supply sides in economics. Nigeria as one of the developing countries in Africa, despite the fact that the country is one of the richest and most populous countries in the continent has relatively low life expectancy at 50 years, and even negative relationships between economic growth and growth variables from empirical studies. These are seen as indication of low level of development in the country despite its rich resources. This paper therefore used analytical technique and descriptive statistics to examine some of the reasons for low economic growth/development in Nigeria using secondary data from World Bank, and Central Bank (CBN). A deepening poverty; corruption, unemployment, poor infrastructures, inadequate capacity for socio-economic management; poor leadership, a low per capita income and others were found existing as obstacles to growth. The steps already taken by the country for development were identified as banking reform, poverty alleviation programmes and others. However, recommendations were made for better economic growth of the economy based on the causes of low growth of the country like corruption, fluctuating real GDP, poverty, poor governance and others and the recommendations of DOHA International Conference for development.

Bombuwela ,and De Alwis (2013) conducted a study on effect of Glass Ceiling on Women Career Development. The overall study was structure based on the conceptual framework built up using the information of literature survey. The study was conducted with the aim of obtaining the following objective. That is "To find out the Effect of Glass Ceiling on Women Career Development with regard to female executive level employees who are working in private sector organizations." At the same time, hypotheses are developed to find out whether there is a significant effect of Individual Factors, Family Factors, Organizational Factors and Cultural Factors on Women Career development. Merely this study has been completed with an empirical survey which was thoroughly conducted using a self-administered questionnaire and the sample consisted of 150 women executives. For presenting and analyzing the data both descriptive and inferential statistics were used. The findings reveal that the Glass Ceiling and Women Career Development have a moderate negative relationship, and also show that Individual Factors, Organizational Factors and Cultural Factors have a significant effect on Women Career Development whereas Family Factor has effects on the Glass Ceiling. Following the study results, a conclusion was eventually made that there are significant effects of the Glass Ceiling on Women Career Development of Executive level female employees working in private sector organizations in Sri Lanka

\section{Methodology}

The study was carried out using survey design. Primary data were obtained through the use of questionnaire, interview and observation while the secondary data was obtained through the use of text book, Journals and internet. The populations of the study were 3152 drawn from the Female employees of Access bank and Diamond bank Plc. A sample size of 354 was determined from population using Taro Yamane's sample size determination method. The instrument used for data collection was questionnaire structured in four point likert scale and validated with content validity of face to face approach. The reliability test was done using test re-test method. The result gave a coefficient of 0.96 indicating a high internal consistency. three hundred and fifty-four (354) copies of the questionnaire were distributed and three hundred and thirty four (334) copies were returned while twenty (20) were not returned. The hypothesis formulated was tested at 0.05 level of significance.

\section{Data Analysis and Discussion}

The data obtained from the field were presented and analyzed with descriptive statistics to provide answers for the research questions while the corresponding hypotheses were tested with Pearson's Correlation and Linear regression at 0.05 alpha level. 
International Journal of Management and Information Technology

What are the effect of female career development on performance Money Deposit Banks.

Table 1: Coded Responses on career development and performance.

\begin{tabular}{|l|l|l|l|l|l|}
\hline $\mathbf{s} / \mathbf{n o}$ & Questionnaire items & $\begin{array}{l}\text { S.Agree } \\
\text { /Agree }\end{array}$ & $\begin{array}{l}\text { Disagree } \\
\text { /S.Disagree }\end{array}$ & Undecided & \\
\hline 1 & $\begin{array}{l}\text { Female career development promotes } \\
\text { employee performance }\end{array}$ & 284 & 35 & 15 & Freq \\
\hline 2 & $\begin{array}{l}\text { Productivity can be enhance through female } \\
\text { career development }\end{array}$ & 318 & 10 & 5 & 334 \\
\hline & TOTAL & 602 & 45 & 20 & 668 \\
\hline
\end{tabular}

\section{Source: fieldwork 2015}

According to table (1) based on aggregate response 335(90\%) indicated strongly agree, $45(7 \%)$ indicated disagree while $20(3 \%)$ indicated undecided. This implies that female career development significantly affect performance of money deposit banks

$\mathrm{Hi}$ : Female career development significantly affect performance of money deposit banks

Table 2 Model Summary ${ }^{\circ}$

\begin{tabular}{|l|r|r|r|r|r|r|r|}
\hline Model & $\mathrm{R}$ & $\mathrm{R}$ Square & $\begin{array}{l}\text { Sum of } \\
\text { square }\end{array}$ & $\mathrm{F}$ & $\mathrm{T}$ & $\begin{array}{c}\text { Adjusted } \\
\mathrm{R} \\
\text { Square }\end{array}$ & $\begin{array}{l}\text { Std. Error of } \\
\text { the Estimate }\end{array}$ \\
\hline 1 & $.766^{\mathrm{a}}$ & .634 & 62162 & 52.362 & 13.191 & .132 & 1.08957 \\
\cline { 4 - 7 } & & & 401.262 & & & & \\
\hline
\end{tabular}

a. Predictors: (Constant), discernable pattern of efficiency

b. Dependent Variable: waste disposal technique

$\mathrm{R}$

$\mathrm{R}^{2} \quad=0.134$

$\mathrm{F} \quad=52.361$

$\mathrm{T}=13.191$

DW $\quad=0.075$

Interpretation :

The regression sum of squares (62.162) is less than the residual sum of squares (401.262), which indicates that more of the variation in the dependent variable is not explained by the model. The significance value of the $\mathrm{F}$ statistics $(0.000)$ is less than 0.05 , which means that the variation explained by the model is due to chance.

$\mathrm{R}$, the correlation coefficient which has a value of 0.766 , indicates that there is positive relationship between female career development and performance. R square, the coefficient of determination, shows that $63.4 \%$ of the variation in the waste disposal technique is explained by the model.

With the linear regression model, the error of estimate is low, with a value of about 1.08957 The Durbin Watson statistics of 0.075 , which is less than 2 , indicates there is no autocorrelation.

The female career development coefficient of 0.766 indicates a positive significance between female career development and performance, which is statistically significant (with $t=13.191$ ). Therefore, the null hypothesis should be rejected and the alternative hypothesis accordingly accepted. Thus there is female career development significantly affects performance of money deposit banks 
What are the obstacles of female career development in money deposit banks?

Table 3 Coded Responses on female career and money deposit bank.

\begin{tabular}{|l|l|l|l|l|l|}
\hline S/no & Questionnaire items & $\begin{array}{l}\text { S.Agree } \\
\text { /Agree }\end{array}$ & $\begin{array}{l}\text { Disagree } \\
\text { /S.Disagree }\end{array}$ & Undecided & \\
\hline 1 & $\begin{array}{l}\text { Gender inequality is a constraint to career } \\
\text { development }\end{array}$ & 304 & 25 & 5 & Freq \\
\hline 2 & $\begin{array}{l}\text { Female career develop can be hinder } \\
\text { through glass ceiling }\end{array}$ & 314 & 15 & 5 & 334 \\
\hline 3 & $\begin{array}{l}\text { Cultural factors limit female career } \\
\text { development }\end{array}$ & 224 & 64 & 46 & 334 \\
\hline & TOTAL & 842 & 104 & 56 & 1002 \\
\hline
\end{tabular}

\section{Source: fieldwork 2015}

According to table (3) based on aggregate response 842(84\%) indicated strongly agree, 104 (10\%)indicated disagree while $56(6 \%)$ indicated undecided. This implies that Glass ceiling, Gender inequality and cultural factor are the obstacles of female career development in money deposit banks

Hi: Glass ceiling, Gender inequality and cultural factor are the obstacles of female career development in money deposit banks

Table 4 : Chi-Square Tests

\begin{tabular}{|l|r|r|r|}
\hline & \multicolumn{1}{|c|}{ Value } & Df & \multicolumn{1}{c|}{$\begin{array}{c}\text { Asymp. Sig. } \\
\text { (2-sided) }\end{array}$} \\
\hline Pearson Chi-Square & \multicolumn{1}{|c|}{$136.379(\mathrm{a})$} & 20 & .000 \\
Likelihood Ratio & 149.723 & 20 & .000 \\
Linear-by-Linear & 46.039 & 1 & .000 \\
Association & 1002 & & \\
N of Valid Cases & & & \\
\hline
\end{tabular}

Table 4 is the output of the computed Chi-Square values from the cross tabulation statistics of observed and expected frequencies with the response options of agree and disagree all based on the responses of the research subjects . Pearson Chi-Square computed value $\left(X^{2}{ }_{c}=136.379\right)$ is greater than the Chi -Square tabulated value $\left(X^{2}{ }_{t}=31.419\right)$ with 20 degrees of freedom (df) at 0.05 level of alpha $\left(X^{2}{ }_{c}=136.379, p,<.05\right)$

\section{Decision Rule}

The decision rule is to accept the alternate hypothesis if the computed Chi-Square value is greater than tabulated ChiSquare value otherwise reject the null hypothesis.

\section{Decision}

Since the Pearson Chi- Square computed $X^{2}{ }_{c}=136.379$ is greater than Chi- Square table value $X^{2}{ }_{t}=31.419$, the null hypothesis is rejected and alternate hypothesis is accepted. Thus, we conclude that glass ceiling, gender inequality and cultural factor are the obstacles of female career development in money deposit banks

\section{Findings}

The findings at the end of this study include the following:

1 Female career development significantly affects performance of money deposit banks $\quad(r=0.766 ; t=13.191 ; F$ $=52.361 ; p<0.05$ )

2 Glass ceiling, Gender inequality and cultural factor are the obstacles of female careerdevelopment in money deposit banks $\left(X^{2}{ }_{c}=136.379,>X^{2}{ }_{t}=31.419 ; p,<.05\right)$

\section{Conclusion}

The study concluded that women world-wide can be seen joining the workforce in large numbers. Women managers globally are described as having to deal with blocked mobility, discrimination and stereotypes. 


\section{Recommendations}

Based on the findings of this study and the conclusions drawn there- from, the following recommendations were made.

(1) The equality theory should be adopted in any money deposit banks, and gender issues should be a thing of the past, but employee input should determine their reward system and promotion.

(2) In order increase productivity government should empower women and protect their labour rights and the environment through which the policies are put in place.

(3) Organizations should ensure that their human resource policies and strategies focus on promoting recruitment and development of female managers at work was a deterrent to gender diversity.

\section{REFERENCE}

1. Bain, O., and Cummings, W. (2000). Academe's glass ceiling: Societal, professional organizational and institutional barriers to the career advancement of academic women. Comparative Education Review, 44(4), 493-509

2. Banducci, B. (2002). Equality and Equity - Equal \& Different. http://www.womensmedia.com

3. Blumberg, R. (1987). Organizations in Contemporary Society. Englewood Cliffs, NJ: Prentice Hall.

4. Bombuwela P. M., De Alwis A. Chamaru (2013)effect of Glass Ceiling on Women Career Development Journal of Competitiveness, Vol. 5, Issue 2, pp. 3-19,

5. Caligiuri, P. M., and Tung, R. (1999). Comparing the success of male and female expatriates from a us-based company. International Journal of Human Resource Management, 10(5), 163-179.

6. Catalyst Organization. (2004). Women "take care", Men "take charge" Stereotyping of U.S. business leaders exposed".(http://www.catalyst.org/files/full/women).

7. David (2014) Moderator Effects of Gender in the Job Insecurity - Career Engagement Relationship: A Nigerian Study, International Journal of Business and Management; Vol. 9, No. 6;

8. Maxwell, P. W. (2007). Success strategies for the female project manager [Seminar Paper]. PMI Global Congress, North America Atlanta, GA.

9. Nieva, V. F., and Gutek, B. A. (1981). Women and work: A psychological perspective. New York: Praeger

10. Omair K., (2008) Women in management in the Arab context, Education, Business and Society: Contemporary Middle Eastern Issues, 1(2), 107-123

11. Osibanjo, Oyewunmi, and Ojo, (2014) Career Development as a Determinant of Organizational Growth: Modelling the Relationship between these Constructs in the Nigerian Banking Industry, American International Journal of Social Science Vol. 3, No. 7

12. Perloff, R.O. (eds). Psychology and work: productivity, change and employment. Washington

13. Satope (2014) Finance, development and growth in Nigeria: Obstacles, steps adopted and DOHA recommendation, Merit Research Journal of Accounting, Auditing, Economics and Finance Vol. 2(2) pp. 012-021

14. Savage, A. W. (2002). The Real Glass Ceiling, http://www.wipcoaching.com Accessed on 20th August, 2012

15. Sen, Kandpal and Tinani (2013) Road to the top- barriers faced by women in the financial sector in Oman Research Journal of Management Sciences .Vol. 2(9), 1-6,

16. World Bank, Priorities and Strategies for Education: A world bank review (Washington DC, 1995)

17. Zippel, K. (2002). Sexual Harassment and Transnational Relations: "Why those concerned with GermanAmerican relations should care. http://www.aicgs.org Accessed January, 2013 